\title{
Oceans of Non-Relation: Affect and Narcissistic Imperialism in Sea Poetry by James Thomson, Charlotte Brontë, and Hannah More
}

Caroline Koegler

\section{Introduction}

A commonplace perception situates the British empire as an "empire of the seas" (Armitage 2004: 100). The ocean, surrounding the British Isles on all sides, encouraged as much as necessitated Britain's expertise at shipping and seamanship on its path to imperialism. Often seen as accelerating with the defeat of the Spanish Armada in 1588, British imperialism rose to prominence in the mid-eighteenth century after the Seven Years War against France that ensued in 1756, with Britain seeking to expand its power and territory in North America. Peace was restored through the Treaty of Paris in 1763, which gave Britain Canada, Grenada, and the Floridas, and significantly reduced French as well as Spanish influence on the North American continent. A good twentyfive years before, in 1740, James Thomson anticipates Britain's unfolding imperialist dominance in his infamous nationalist poem "Rule, Britannia!"1 As a military and political entity, empire is still a "more wishful prospect than reality" (Nyquist 2018: 74) when Thomson's text amalgamates ideological undercurrents of empire that have long been in the making. The brutal quenching of Bacon's Rebellion in 1675 and the introduction of slave $\operatorname{codes}^{2}$ in the Americas, for example, both have already been indicative of a gradual popu-

1 In the following, I am citing James Thomson (1740).

2 From the end of the seventeenth century, communities "from Barbados to Maryland" introduced "comprehensive slave codes" (the bulk before c.1730), consolidating the position of planters and establishing their absolute rule over the lives of enslaved people (Synder 2015: 82). 
larisation of imperial expansionism and, particularly, racialisation. ${ }^{3}$ Within this lineage, "Rule, Britannia!" is part of a larger historical moment in which the ideology of empire is transferred into "normative self-conception" (see Armitage 2004: 172). Each stanza, ending on emphatic pronunciations of denial and disavowal ("Britons never will be slaves"), cements the impression of a superior and supremacist Britain whilst simultaneously revealing a victimological strategy that conjures Britain's need of protecting itself against the injury and shame associated with the position of the enslaved. It predicts not only Britain's soon-to-be increasing political and military influence in the Atlantic world, but also facilitates performative entrainment of exceptionalism and, as this chapter argues, narcissistic non-relation, effected through language, form, and affect.

For the purpose of this chapter, "Rule, Britannia!" is understood as a powerful manifestation of an imperial politics of emotion, fostering exceptionalist self-perception at a crucial moment in the history of the British empire. Positioning enslaved others as a source of negative feeling and engaging in their (attempted) abjection, the poem disavows Britain's historic role in mass enslavement. It also performs an imperialist entitlement to signification that includes emotional attribution and the management of relation, tailoring 'relating' in ways that undermine the idea of other people's subjecthood and entitlement (to well-being, self-determination, recognition etc.). In charting imperial Atlantic negotiations of affective avowal and disavowal across a span of c.100 years, I will explore, in the following, how "Rule, Britannia!" engages in selective non-relational strategies (objectification, abjection), and how it and two other poems - Charlotte Brontë's "The Letter" (1846) and Hannah More's “The Sorrows of Yamba” (1999 [1795]) - negotiate this process via oceanic imagery. All poems prominently feature the sea: as a controlled subject as well as background to and mobilizer of Britain's rapidly expanding empire (Thomson); as a lamentable obstacle separating two lovers in an age of accelerating colonialism (Brontë); and as a counter-discursive sphere that can be used to challenge the morality of colonialism and the slave trade, indeed

Francois Bernier's A New Division of Earth By the Different Species or Races Which Inhabit It (1684), Carl Linnaeus' differentiation of different 'races' in Systema Naturae (1735), and Georges Louis LeClerc, Comte de Buffon's thirty-six volume Histoire Naturelle (17491788) are just some examples for works that are precursors of scientific racism, linking differences in physiognomy to different 'races' and hierarchizing them according to deviation from the 'white prototype' (see, e.g., Seth 2018: 176). 
the very grandiose self-perception laid out in Thomson's poem (More). I am interested in how and where these texts position the sea to function both as a conveyer of imperial ideology and contact zone between metaphoricity and (wilful) materiality, even against their own imperialist grain, i.e., how they convey oceans as "a deeply historical location whose transformative power is not merely psychological or metaphorical [...] but material and very real" (Klein/Mackenthun 2004: 2); and how they cloud the morality of the imperial project by demonstrating, particularly, imperialism's affective deficiencies.

These affective deficiencies emerge most forcefully in the non-relation exhibited in the texts toward kidnapped and enslaved Africans transported to the Americas and their deaths in the waves. As meticulously argued by Terri Synder in The Power to Die (2015), for centuries, the waves bear the bodies of people who choose suicide over enslavement. In conditions of stark disempowerment, on the Atlantic, "Africans' suicides gave enslaved people a fleeting, if fatal, leverage, and the spectres of their self-inflicted deaths haunted the Atlantic trade" (41). Attempts by Europeans to prevent this are frustrated, as emerges from their "chronicle[s] [of] the actions of enslaved cargoes who killed themselves by leaping overboard, strangulation, or refusing to eat" (41). The waves also carry those bodies cast overboard by whites ${ }^{4}$ seeking to discourage self-killings; they are fed to the sharks to underscore a lack of ceremonial burial (40). Yet people are also drowned by captains for economic advantage, as suggested by one of the most memorable court cases in British history, the Zong Trial in 1783. As such, if 'rule the waves; / Britons never will be slaves' is Thomson's motto, then this act of abjection not only heavily downplays efforts of resistance, often collective, on the part of the enslaved, it also reveals the sinister nature of "Rule, Britannia!", encapsulated in the materiality of those Atlantic waves that carry the dead bodies upon which Britain sails to prosperity - the "commerce" with which, as Thomson euphorically suggests in the poem, Britain's cities shall "shine".

In the present chapter, I discuss this nexus of oceanic materiality and affective non-relation under the heading of oceans of non-relation - a concepcategory at the time in which some of the texts here discussed are published. While I occasionally use 'white' and 'black' as signifiers of different positionalities, this usage is tentative á la Seth, acknowledging that physiognomy is increasingly categorized and valorized according to its degree of deviation from the 'white prototype' (see, e.g., Seth 2018:176). 
tual convergence partially inspired by Judith Butler's concept of 'grievability' and by research on comparing and imperial narcissism. Butler defines grievable life as life that "can be valued, and valued through time" (2015: 198); life that "conform[s] to certain conceptions of what life is, in order to become recognizable" (2016: 7). The poems exhibit the imperial power of determining the very coordinates of 'life,' of life worth living and life worth mourning, in paradigmatic form. I use 'non-relation' to denote all those directions into which recognisability - we might also say Adam Smith's more contemporaneous "fellow-feeling" (1759: 14) - does not expand as a result of such 'coordination,' which is a type of coordination that normalizes the notion of a lack of subjecthood and agency in the other. How is this achieved? This chapter suggests this is done through establishing an epistemological-affective process that combines attribution, comparing, and narcissistic disavowal. According to Antoine Berman, comparing has a translatory function that seeks "to open up in writing a certain relation with the Other, to fertilize what is one's Own through the mediation of what is Foreign" (1992: 57). However, such relating is also "diametrically opposed to [...] that species of narcissism by which every society wants to be a pure and unadulterated Whole" (Berman 1992: 4; my emphasis). Narcissism remains an underconceptualized term in Berman's study on German Romanticism, just as 'comparability' and 'incomparability' perform only an auxiliary role in his focus on 'translation.' In conjoining narcissism with the thematic complex of comparing, however, and also by stressing the frictions between "ethnocentric translations" and those that facilitate "an opening, a dialogue, a cross-breeding, a decentering" and "a putting in touch with"' (ibid.), Berman lands us squarely in the epistemological-affective machinations of Euro-imperialism. Stained by ulterior motives, in the context of imperialism, comparing easily follows carefully engineered paths that protect privilege and power. In this context indeed, "comparisons are never neutral: they are inevitably tendentious, didactic, competitive, and prescriptive" because "[t]he epistemology of comparison is willed into existence by a certain will to power/knowledge" (Radhakrishnan 2013:16). It is because of comparing's intimacy with power-knowledge that the former might also forestall, rather than foster, relation, and it can do so in ways that potentially surprise in their flexibility of deploying comparability tropes. As Stanford Friedman also signals with her concept of "in/commensurability":

On the one hand, comparison compels recognition of commensurability likeness - but on the other hand, comparison acknowledges incommensura- 
bility - difference. [...] Comparison puts incommensurability and commensurability into dynamic interplay reflected in the slash that separates and connects: in/commensurability. (40)

Such 'in/commensurability,' where tying in with the power of signification, exhibits a privileged flexibility, i.e., can deploy comparability and incomparability to accommodate different, at times opposing ends. ${ }^{5}$ For example, incomparability can be used to denote exceptionalism, as much as comparability can be used to reinforce comparative superiority and stronger claims to entitlement. As such, in/comparability can be situationally tailored to imperialist goals - a process that also relies on a strategic usage of people ('foreign' people, enslaved people) whom it can incorporate and "compel in a variety of ways to reflect back to the imperialist a grandiose self-image" (Simmons 2007: 1). This brings us back to the concept of non-relation. As Diane Simmons writes in The Narcissism of Empire, a narcissistic deployment of (signifying) power objectifies others and turns them into objects of use. Unable to perceive of others as partners or subjects with agency, feelings, motivations or motives independent of the wishes of the narcissist, narcissism describes a subject position "Enchanted by an 'other' who is nothing but his own reflection" signalling an "incapab[ility] of relating to a real other" (Spivak 1993: 32, see Drichel 330). In her own work on "The Disaster of Imperial Narcissism", Simone Drichel also highlights Leela Gandhi's observation of colonialism's "crisis of nonrelation" (2018: 184) and the "antirelational basis of imperialism" (185). While this suggests immense power on the part of the colonizer, it is important that non-relationality, or even antirelationality, still depend on the other's existence; still depend on in/comparability as a mechanism of harnessing others to nurture a grandiose self-image. Hence the spectacle, one could argue, of a perpetual, even frantic rehearsal of comparative superiority and comparative claim in Thomson's poem, alongside claims to essential incomparability encapsulated in the idea of godly intervention or the totalising abjection of enslaved peoples (which erases any agency or resistance on their parts). Herein then ultimately also lies a degree of (white) fragility in the narcissistic foundations of Euro-imperial non-relation and in/comparability. ${ }^{6}$ As repeat-

5 I have discussed this type of privileged flexibility elsewhere: in relation to colonial discourse's strategic de-/re-/ and post-humanisations of racialized others (Koegler 2020). Bakary Diaby has provided a broader discussion of 'white fragility' in relation to Romanticism, utilising DiAngelo's explanation of "a state in which even a minimum amount of racial stress becomes intolerable, triggering a range of defensive moves" 
edly emphasized by research on narcissism, this includes erratic behaviour on the part of the narcissist when faced with attempts at defying their narcissistic power. Such defiance easily triggers a particularly destructive, narcissistic rage that can turn into desperation and depression when it cannot transform resistance into compliance, meaning that the process of objectification and mirroring breaks down. Triumphant or grandiose engagement in in/comparability can similarly collapse, an idea latent, for example, in Felski and Stanford Friedman's pondering if comparison might "decenter [and] unsettle standards of measure rather than reinforce them" (2013: 1), or even produce "a jolt to consciousness, initiating a destabilizing, even humbling, awareness of the limitedness and contingency of one's own perspective" (2). In the following, I analyze these productive tensions between in/comparability and non-relation, narcissism and vulnerability, ocean and affect, as well as metaphor, materiality, and resistance, by dedicating a sub-chapter to each poem. Towards the end, I will be interested in reaching beyond imperial narcissism as a meaning-making framework.

\section{James Thomson's "Rule, Britannia!" (1740) and the Burden of Shame}

James Thomson's exceptionalist-nationalist poem envisages Britain's “[rise] from out the azure main" as a form of Godly intervention. The angels' supposedly very own, emphatic declaration "Rule Britannia, rule the waves; / Britons never will be slaves" is repeated at the end of every single stanza and uncannily underscores the narcissistic necessity of perpetually re-inscribing incomparable superiority (also: beauty) and comparative liberty (Britons "never will be" 'like slaves'). Euphoria over Britannia's freedom here lies frightfully close to an endemic fear of power reversal: to be put in the position of 'slaves,' a status that Britain has itself created for so many people for the sake

(DiAngelo 2011: 54, see Diaby 118), including "weaponized emotion" (Diaby 118) such as white "anger" and "fear" (DiAngelo 2011: 54). According to Diaby, one of the "key aspects" for Romanticism is "the drive to keep whiteness meaningless" (123). It also "holds racism in place' by keeping whiteness invisible and marking moments of its visibility as an upsetting to the natural(ized) order" (4). As a result, the very possibility of or attempt at breaking out of such a relationship is a minefield where white pain marks any impending levelling of hierarchies or resistance as a shameful violation of the 'natural' order of things. 
of expansion and enrichment, is the shameful prospect 'Britannia' is confident to avoid - as long as she rules. With this juxtaposition, Thomson follows a conventional line of worlding that uses signifying power to attach shame to the position of 'the slave' (see Nyquist 2018: 69), indeed semantically collapses one into the other. This ostensibly effects detachment and distantiation from the experience of enslavement, however, the frequent, rhythmic repetitions of denial and also the proliferating, multi-referential semantics of enslavement that are used in the poem ultimately indicate that Thomson is on slippery ground, the control over signification nearly escaping him. As spelled out by Mary Nyquist, “'Rule Britannia' (1740) memorably evokes (1) personal, (2) internal political, and (3) external political slavery as a nearly magical, indissoluble trinity" (2018: 74); and further: "the refrain thus sings of determination to safeguard Britannia's external, political freedom" as it "raises the possibility of personal, domestic slavery, that is, of each individual Briton being enslaved to an individual slave-holder" (74-75). Nyquist's nuanced observation hints at the overwhelming realness attributed by the poem to the proposition of Britons' potential, multi-dimensional enslavement, conjuring a degree of dread that is absent where Thomson envisages the (potential) enslavement of others. This unevenly spread dread and grievability (as per Butler's conceptualization) signals an affective eclecticism that is similarly revealed in Thomson's claim 'Britons never will be slaves'. The claim implies an exceptionalism that is, in fact, historically incorrect, given the history of Roman slavery in Britain or, more contemporary to Thomson, instances of North African slavery ${ }^{7}$ that were still an occasional feature at the time. It also ignores white indentureship such as in the Chesapeake colony where servants conventionally refer to themselves as 'slaves', the terms 'slave' and 'servant' often being used "interchangeabl[y]" (Todd 2010: 3174/7148 [Kindle Locations]). Another caveat lies in gendered power; Thomson's insistence on "Britons" forever defying enslavement is incompatible with historically increasingly popular, proto-feminist positionings of women as 'slaves' in a hetero-patriarchal society. While white feminist appropriations of the materially and politically very different experience of enslavement might count as another textbook case of 'why not compare', i.e., signal a problematic entitlement or 'access' to empire and its subjects, these perceptions are nonetheless becoming virulent in Thomson's form of abduction and enslavement of Britons in the North African region, in the early modern period. For details, see works by Colley, Davis, MacLean and Matar. 
time with "Writers ranging from Mary Astell to Mary Wollenstonecraft [sic!] to Jane Austen [...] insist[ing] with varying degrees of vehemence on the slave status of supposedly free women in Britain" (Swaminathan/Beach 2016: 10). Thomson's 'management' of the slavery trope thus not only reveals a gendered standpoint, but also carefully circumnavigates some of the blots on his advocated idea of Britain's singular liberty. At the same time, however, he does not - or: chooses not to; cannot - entirely shake off negative affect such as dread or fear where it pertains to a potential reversal of the status quo; to a potential (re-)enslavement of Britons. This, of course, ultimately indicates the fragility, even paranoia, of a not yet so firmly established and consolidated empire possibly seeking to harness such fragility through a particularly kind of aggressive rhetoric.

As this already implies, Thomson's selective conjuring of dread and fear, paired with an at times victimising discourse of self-protection ("determination to safeguard Britannia's external, political freedom", in Nyquist's words) is not only uncanny, but also enabling. As Sara Ahmed illuminates with her concept of a racialized 'fantasy of violation' (see 2015: 62-81), white nationalistic discourse often positions others as a source of fear or dread, thereby warranting and legitimating white self-defence (control, exclusion, etc. of the presumed 'threat'). This applies to "Rule, Britannia!" insofar as ascribing negative affect to the fearsomeness of others drives the pretend, moralistic endeavour of maritime imperialism and also legitimizes aggressive militarism. As fear is attached even to the subjugated bodies of the enslaved and/or their condition (a moment of distinct depersonalisation), negative emotion is attributed from the signifying position - an attribution that legitimates enslavement of others as a pseudo-preemptive move. Here is also the "psychic use" that Simmons suggests the subjected fulfil from the perspective of their narcissistic conquerors (2007: 1). In addition to couching abuse, aggression, and enslavement in moral righteousness, Simmons suggests that enslaver-enslaved relations "provided rich opportunities for expressing feeling of contempt, ridicule and revulsion, allowing the imperialist to displace onto others his own feelings of shame and self-contempt" (ibid.). In this instance, Nyquist's and Simmons' arguments overlap; while Nyquist accentuates the self-protective stance of Thomson's text (slavery as the shameful prospect against which Britons need to protect themselves through military and political agitation), Simmons can be read as implying another kind of self-protection: where enslaved peoples become receptacles for displaced colonial shame and fear, they become objects of use insofar as their distantiation facilitates a distancing from uncomfort- 
able emotions, i.e., from emotions that might endanger white confidence or entitlement to rule. If the former position legitimates casting aggression as self-protection (also encapsulated in the lines "Still more majestic shalt thou rise, / More dreadful from each foreign stroke;"), the latter enables a cleansing of the imperial project of uncanny, bad feelings that might obstruct the moral smoothness with which Britain glides to power.

The moral-affective defence mechanisms installed by Thomson help normalise a stance that readily accepts the doom of others. Be they enslaved or stem from other European nations, Thomson seems to embrace a social Darwinist perspective avant la lettre that preferably considers a lack of well-being in others as collateral damage ("The nations, not so blest as thee, / Must, in their turns, to tyrants fall;"). At times steeped even in Schadenfreude, the losses experienced by other 'nations' seem to be predominantly conjured to offset Britain's exceptional prosperity and self-determination ("While [Britain] shalt flourish great and free, / The dread and envy of them all"). Thomson's assertions thus also resonate with what Philip Wüschner has described as a form of narcissistic shame that is severed from remorse and notions of social responsibility. Narcissistic shame represents "the inverted picture of narcissistic rage that does not really care for the ones who have been wronged but only grieves the loss of social recognition" (2017: 99, see Malreddy 2019: 314). Following Wüschner, Malreddy has similarly suggested that "shame is not only a contingent emotion, but also a necessary trigger for a proper understanding of guilt" (2019: 314). This is highly relevant also for deciphering Thomson's narcissistic poetics of imperialism, as he repeatedly foregrounds the glory of a Britain that deeply humiliates other European nations, who in turn 'envy' Britons their unbounded power/freedom. Thomson thus implies that it is the 'loss of social recognition' that subjected nations will primarily invest with negative emotions, rather than the pain and losses experienced by their peoples. What is played on here, in other words, is the idea of one narcissist subduing another.

A central streak in this narcissistic-imperialist hustling for supremacy military, political, and moral - is ensuring a compartmentalisation, and finally, abjection, of "'the not" (Ahmed 2015: 86). Affectively speaking, 'the not' the shameful and fearsome idea of inferiority and suppression of the self - is tentatively secured through a stance of disgust at "that which is below" which "functions to maintain the power relations between above and below, through which 'aboveness' and 'belowness' become properties of particular bodies, objects and spaces" (89; original emphasis). Shame plays a central role here. Disgust ten- 
tatively overwrites shame or, more to the point, turns it into the burden of others, simultaneously consolidating colonial hierarchies. It is these affects' close proximity to one another - shame, fear, disgust (Simmons speaks of "contempt, ridicule and revulsion" as essential to narcissistic objectification) - that consequently further contextualizes Thomson's strong language in positioning "Britannia" over others. The same proximity also explains Thomson's oscillations between such different emotions as euphoria and dread, confidence and shame/fear/disgust, and as such between stark avowal and disavowal. Britannia's burgeoning 'rule', or so Thomas ultimately suggests, is dependent not only on military or even ideological prowess, but also on fostering affective supremacy - an enterprise that is as violent and demanding as it is precarious.

\section{3. "Sent from England's Shore": Charlotte Brontë's "The Letter" (1846)}

"The Letter" was published in 1846 and as such a good hundred years after "Rule, Britannia!" It appeared in an anonymous collection by the Brontë sisters one year before the sisters began to publish their first major novels. The poem of seven stanzas - which has not received much scholarly attention - in many ways appears as a condensed version of some of the dynamics negotiated in, particularly, Jane Eyre and Emily Brontë's Wuthering Heights, published only two years later. The similarities between the texts prominently include reference to Britain's continuing imperial entanglements overseas and the emotional burden of empire that white families carry as a result of colonialism. They both are energized by fears of reverse-colonisation at the affective level, Rochester and Jane being pitted as suffering from Bertha's excruciating presence and the Earnshaws and Lintons from Heathcliff, the retaliating, racialized orphan-incomer. As I argue elsewhere, the novels' set-ups are deeply steeped in imperial economies of emotion, in so far as they position racialized others as the "origin of bad feeling" ${ }^{8}$ which ostensibly legitimates their subjection and exclusion (in Bertha's case, of course, after Rochester has already taken her fortune via marriage). Bertha and Heathcliff are also depicted as inducing dread insofar as they supposedly threaten white health, genealogies, (one of Wuthering Height's narrators) own words (see Koegler 2021: 273, 283). 
and property relations, whilst at points also proving dangerously alluring in tune with miscegenation fantasies that were prominent at the time. As such feeding classic imperial 'fantasies of violation', the thematically closely related texts position disavowed, colonial subjects in the position of the aggressor (see Koegler 2020, 2021) and manufacture a need for white self-preservation that pushes back against racialized others. Once this push-back is complete and the racialized other is removed, reconciliation, relief, happiness, and the prospect of white procreation are restored.

Whilst Charlotte Brontë's "The Letter" does not personify the danger of reverse-colonialism via a Bertha or Heathcliff figure, it nonetheless already follows the bulk of affective strategies realized in more detail in Jane Eyre and Wuthering Heights. Like the novels, "The Letter" dramatizes negative impacts of Britain's overseas imperial entanglements on the British domestic scene. It is here encapsulated in a married couple's separation in the name of advancing the imperial endeavour. While the young wife pines for her husband, artificially confined to a desk in the bloom of her youth and bent over her letter, he, "loved though stern", is "detain[ed]" by "[r]emote colonial wilds" - an information revealed at the climactic end of the poem. Differently put, the poem couches the imperial endeavour as a sacrificial, white burden whose spectacle of titillating harm is displayed upon the mind, body, and emotions of a young white woman. As my language here suggests, the poem also already contains some of the erotic innuendos more overtly insinuated in the novels.

"The Letter" gives off an impression of haste and breathlessness. Readers hit the ground running: "What is she writing? Watch her now, / How fast her fingers move! / How eagerly her youthful brow / Is bent in thought above!" Question followed by request, followed by two exclamations - the alternating rhyme hurries readers along the lines and mirrors the 'hastiness' of the writer. Astonishment at the zeal and eagerness of this young woman is clearly registered; she is writing fast, her posture mirroring the intensity of her focus; she does not take heed of anything else. The remaining lines of the first stanza emphasize this very sentiment: her hair is obstructing her vision, she moves it carelessly aside. She does not notice as her "band of crystals" falls to the ground. Only as we reach the end of the stanza is it briefly implied that this unlikely stance bears romantic influences ("labour sweet"), and yet this is not fully explored until much later, the next three stanzas functioning as a retarding moment, heaping more mystery, even exasperation, upon the yet unanswered question: "To whom, then, doth she write?" 
Before the crucial answer is provided, the unnaturalness of the young woman's occupation is repeatedly underscored by way of a Shakespearean comparison 'to a summer's day'. It is the "loveliest hour" of a "golden" day in June; nature is in full blossom, like herself, and yet, as the sun goes down, it has "not caught her eye". The speaker's performance of disbelief is still intensified as nature is endowed with human feeling, even flirtatiousness: "The cheerful lawn, and unclosed gate, / The white road, far away, / In vain for her light footsteps wait". Nature here functions not only as a mirror image (she, also, is 'in bloom') but also as a metaphorical lover, waiting for her teasing, "light footsteps". The tempting, "unclosed gate" might well be read as a fertility metaphor, the young woman's unnatural confinement and separation from her lover for now acting as a barrier against procreation. Not insignificantly for such a reading, the phallic "[t]all plants of bright and spicy bloom" that grow "[a]round the threshold" anticipate the introduction of him as "[a] stalwart form, a massive head, / A firm, determined face". Thoughts of his manly determination and rigidity, the very act of writing the letter, and wetting it with her plentiful tears - all this for now absorbs her attention, or: libidinal energies.

Stanzas four and five raise the tension further while the gaze - the speaker's, the woman's, the reader's - become still more important. Readers are overtly directed to look 'more closely', repeatedly encouraged to match her "eager will" with eager eyes: "Nay, watch her still more closely, ask / Her own eyes' serious light; / Where do they turn, as now her pen / Hangs o'er th'unfinished line? / Whence fell the tearful gleam that then / Did in their dark spheres shine?" The long postponed and still cryptic answer approaches at the end of stanza five after a further, incremental narrowing and focusing of the reader's gaze: "But look again; inured to shade / Your eyes now faintly trace / A stalwart form, a massive head, / A firm, determined face". The sixth stanza adds more detail, revealing some exotic "Black Spanish locks" and "sunburnt cheek", paired however with "A brow high, broad, and white" which unambiguously reveals his race. Similarly unmistakable is the morality of his endeavours, carved on his very brow: "every furrow seems to speak / Of mind and moral might". Still later, at the very end of the poem, this almost unearthly being ("Is this her god?") is revealed to be her comparatively profane "husband". He is her "heart of hearts", currently in "a strange and distant spot" and "Three seas and many a league of land" away. This vast distance the letter "must pass o'ver, / E're read by whom to whose loved hand / "Tis sent from England's shore". The final lines provide the resolution, 
long awaited, and bring us full circle: "Remote colonial wilds detain / Her husband, loved though stern; / She, 'mid that smiling English scene, / Weeps for his wished return". Depravation, or so these last lines suggest, lies heavily on her. His absence is an imposition they both share and from which they both suffer. The climactic revelation of the addressee being her "husband" dramatizes her attachment and woundedness, signalled by her tears that she sheds isolated from her cheerful and blossoming surroundings.

In directly linking 'her' suffering-cum-libido and 'their' separation to the 'detaining, "Remote colonial wilds", the poem's exoticizing, even sexualising gaze projects agency and aggression onto the very colonial subjects that Britons seek out to sustain and accelerate the imperial cause. This, too, is a fantasy of violation as defined by Ahmed and version of 'the white man's burden', a burden that weighs down the shoulders of a young, beautiful female in the homestead as well as of the analogous "smiling English scene" which, or so is the implication, would deserve better than have its "open gate" ignorantly overlooked. However, carrying the burden of imperialism turns out to be a much more momentous task than failing the appreciation of a trivial summer's day, and even readers are conscripted into proving this truism: they are put into the position of having to scrutinize and finally understand the extent of her commitment - to him, to empire, to writing the letters that will reinforce their connection and relation. This is also enacted aesthetically: the poem's long and drawn-out circulations of the longed-for answers to burning questions - to whom is she writing? Whose is the face in the picture? - are the eroticized wilds through which readers have to wade in order to establish a sense of clarity.

These layers of comparative, sexualized load-bearing - the young woman, her husband, the reader - enlist Brontë's readers for the trans-Atlantic imperial endeavour, relating specific groups to one another (and not others) and encouraging select understanding and empathy - fellow-feeling - in very specific directions. As such, selective grievability plays an important role in the poem's affective universe. It is clearly located, first and foremost, in white people - her, him, even readers (who at Brontë's time would have been expected to be white). They clearly emerge as human-beings with personhood: intellect, understanding, feelings, needs. While the poem meticulously humanizes one group, another is not situated within the realm of the human. Subsumed under "colonial wilds" that "detain" her husband, colonial subjects are starkly deindividualized and dehumanized by comparison, pitted against the 'smiling English scene' and its graceful and energized, if suffering, inhabitant. Thus 
turned into objects of dread, "colonial wilds" are utilized to offset not only the sacrificial, noble, and enduring character of white colonists (who embrace exilic conditions for the sake of empire) but also England's much more delicate moral-cum-natural world that metaphorically shares in shouldering the draining burden that is empire.

Such usage, semantic and affective, of non/relation (for 'selective relation'), comparison, and metaphor reveals "[t]he Letter's" own investment in culturally normalized, imperial-narcissistic structures of affect. Only a select group will "be valued, and valued through time" (Butler 2015: 198) because they "conform to certain conceptions of what life is, in order to become recognizable" (Butler 2016: 7), even at the level of language ('colonial wilds' vs. an individualized couple). "The Letter", penned in white and unsubtly eroticized distress, is a documentation of colonial infrastructures - affective, logistical, technological - that will connect those who have sailed from England with their loved ones who remain at home, intricately interweaving empire's domestic, natural, and colonial geographies; entangling a married couple's own, emotional intimacy with Britannia's rule of seas, lands, and peoples; and drawing a strategic comparison between the conditions of confinement experienced by both genders. In this context, "sent from England's shore" denotes a liminal space ("shore") beyond which lies a great unknown, oceanic realm that 'the letter' has to cross en route to the other side, to reach his very hands. Not only do the waves carry away people like her husband, they also carry her words to that specific yet unspecific ("colonial wilds"), far-away destination. Considering this injection of estrangement and expansion into the affective, domestic realm of the poem, it is all the more significant that Brontë renders gratifying the truly multifaceted, 'white burden' of imperialism that continues to spur Britannia's rule far and wide and even in adverse conditions. While the epistolary correspondence is isolating and distressing to the young woman, it is also a "labour sweet" - a potentially eroticized as much as eroticizing act. This is exactly what is needed for sustaining empire. Valorising conquest and exploitation becomes more readily acceptable if deprivation can occasionally blur into (perceived) pleasure, tantalizingly linking aggression-coded-as-burden to positive, titillating affect. It is an affective-ideological feat here rendered almost to perfection. 


\section{Black Motherhood in the Anglo-Atlantic: Hannah More's "The Sorrows of Yamba" (1795)}

Thomson's and Brontë's poems indicate the long durée of select relating under imperialism, just as they signal the continuing relevance of a critical whiteness studies approach in the context of long eighteenth century literature and the history of emotion. For the last poem that I will discuss, abolitionist writer Hannah More's "The Sorrows of Yamba" (1795), this applies in a similar way, my focus here also complementing recent research on Romanticism and abolitionism such as by Fran Botkin, Manu Samriti Chander, Bakary Diaby, Debbie Lee, Patricia A. Matthew, Helen Thomas, Paul Youngquist, and Joseph Rezek. These scholars have taken issue with the extent to which scholars of Romanticism have marginalized not only black and brown writers, but also topics like abolitionism and enslavement, i.e., topics that might threaten white morality and puncture the affective 'comfort zone' that has been erected around a rather homogenous group of white, and often male, Romantic writers ${ }^{9}$. Chander and Matthew understand canonization in this context as "a continual process of subjugation, a process that works by muting those voices that would call into question the superiority of authorized English literatures" (2018: 433) - and this ties in, of course, with the kinds of cultural 'superiority' and select grievability channelled in individual literary texts á la Thomson's "Rule, Britannia!" or Brontë's "The Letter". The affective mechanisms and politics reproduced in these texts no doubt tie in with the normalized disavowal of some writers and not others, as well as with rejections of themes that are out of line with imperial ideologies of racial supremacy. I am interested in the counterdiscursive potentials of "The Sorrows of Yamba" in this context, as the poem not only centres on black experience but also formulates a direct, explicitly worded challenge of Thomson's "Rule, Britannia!"

Published in 1795, More's "The Sorrows of Yamba" focuses on an African mother and her account of the middle passage, depicting, according to Lee, "black single motherhood [a]s a state of utter desperation" (2013: 168): "the mother tosses her infant into the silvery ocean with this blessing" - and Lee quotes More: study The Black Romantic Revolution. Abolitionist Poets at the End of Slavery (2020). 
Happy, happy, there she lies;

Thou shalt feel the lash no-more;

[...]

Thee, sweet infant, none shall sell,

Thou hast gain'd a wat'ry grave,

Clean escap'd the tyrant fell,

While thy mother lives a slave.

What More describes here resonates with Synder's discussion of child-killings in The Power to Die. Such killings are just one example of the extent to which enslavement threatened family and community attachments and yet, as both Synder and Lee point out, most accounts of such killings are passed down through white records, ${ }^{10}$ at least until around the mid-nineteenth century when a new generation of African American abolitionists relate what is often first-hand experience of the Middle Passage (see Synder 2015: 16). More's rendition, too, is not an 'own-voice' account, and this might be why her idea of "the black mother's singleness, and along with it her despair and destruction", is essentially aligned with white, late eighteenth-century notions of "failed domesticity" (Lee 2013: 167) just as it is aligned with More's own evangelical beliefs that centre on the 'saving' of souls. The risk of this double alignment is, of course, that enslaved black women and their children are victimized and stripped of agency and resistance. In a previous work, "Slavery, A Poem" (1788), More has already written of "the dire victim torn from social life, / The shrieking babe, the agonizing wife! / She, wretch forlorn! is draggd by hostile hands" (1788: 8), etc. More thus "casts slaves into a mode of racial otherness not hitherto integral to female anti-slavery discourse" (Ferguson 1992: 7) and demonstrates the changing conventions in depicting enslaved persons in anti-slavery writings. While anti-slavery texts by white British female abolitionists have long depicted specific and named "slave-protagonists" who "variously resisted their situation" and in specific "geographical sites" (3), this changes around the time of the Parliamentary campaign in 1787 (in the context of which More writes her poem). It then becomes customary to turn enslaved persons into generic individuals largely "unproblematized, unvoiced, unthinking, and unnamed, victims at the mercy of unchristian British

10 Synder details this, listing "traders' letters, masters' diaries, travelers' accounts, and printed discussions of slavery across and beyond the Anglo-Atlantic" in the early modern period and later "legislative petitions and sporadic coroners' inquests" (2015: 16). 
cut-throats" (4). The drawbacks of this change in conventional representation are particularly revealed when considering that, according to Lee, "[t]he verse authored by white men and women and blasted all over England tells a very different story from the documents floating on the edges of history in black women's words and, sometimes, in their own voices" (2013: 168). Lee reads an alternative archive of "Slave complaints, plantation journals, letters, engravings, and narratives" that show black mothers in a variety of scenarios:

She is a fit caregiver, protecting her child's welfare over her own physical safety. She makes sure her children have a rich and stable community comprised of other black women and children that contrasts starkly with solitary middle- and upper middle-class English domesticity. She practices what all mothers, single or not, know to be true: 'it takes a village' to raise a child. (167)

In thus engaging with a new canon of documents, Lee draws out the "kinship bonds, family strength, and community action" between black 'lone' mothers that, or so she shows, did form as a distinct "counter-culture" and challenge to white patriarchal rule on the plantations (168). Against this background in particular, one could argue that More's choice of theme and generic black mother risks producing a black subject that "is granted only a diluted form of humanity grounded in pain and victimhood" (Festa 2010: 10). However, there is still more complexity: More's poem does not depict plantation life but the Middle Passage, where forging such communal bonds as envisaged by Lee would have been particularly difficult given that the people packed on the ships often neither knew each other nor spoke each other's languages. Even more importantly, even if More frames slave trade and enslavement in a way that is tailored to her white contemporaries, this also has the strategic component of lobbying those persons who hold political power. I would therefore suggest that More's 'tailoring' of Yamba's experience to stereotypical images of failed white motherhood (including infanticide) most poignantly reflects less her own preferential views of black motherhood than those normalized in her society - a society potentially unable to relate to the notion of powerfully bonding black mothers, and for all the wrong reasons. More thus no doubt reproduces but also manipulates her own society's normalized, affective politics of non-relation, one in which black mothers become intelligible as grievable only when and if their depiction follows the already disempowering script of failed, white motherhood (which More also, implicitly, criticizes with her depiction; see Ferguson 1992). Indeed, More plays on a practice of recog- 
nition that might reel in one image of victimized motherhood because it can compare to another, already familiar one. Whether intentionally or unintentionally, More's presentation of infanticide in the Anglo-Atlantic thus reveals a knowledgeable navigation of colonial-patriarchal narcissism that might extend its sympathy and might install political change only if and where this reflects morality and power back at the white (male) colonists - a classic white saviour trope. It is a strategy which, like so much of sentimentalist abolitionist writing, largely upholds the imperial-patriarchal emotional grid while aiming for changing the political and economic system: ending the trade in enslaved persons.

If More's victimising representation of black motherhood might then be understood as a covert (as well as limited) strategy of persuasion that is symptomatic of the normalized, colonial-patriarchal narcissism of her time and society, elsewhere, she tackles such narcissism much more overtly through direct references to Thomson's "Rule, Britannia!":

Ye that boast "Ye rule the waves,"

Bid no Slave-ship soil the sea;

Ye that "never will be slaves,"

Bid poor Afric's land be free.

Taking on an egalitarian sentiment, More here demands an equal standard for Britons and Africans where, as per Christian obligation, Britons must not inflict on others what they themselves are so eager and proud to avoid for their own people. Countering Thomson's monopolising as much as perverted notion of 'freedom' (which, apparently, includes the 'freedom' to enslave others), More undermines the normalization of commingled narcissism and essentialism in Thomson's poem. Indeed, with her request for a more egalitarian framework, More goes against imperialism's paradigmatic belief in white supremacy that also informs Brontë's conjuring of the dehumanized and yet threatening "colonial wilds". I am here also reminded of Synder's suggestion that Olaudah Equiano's Interesting Narrative "report[s] that he 'envied' the dead their 'freedom' and did not criticize the suicide attempts of captives aboard ships" (2015: 30). This reveals the extent to which imperial ideology not only normalizes white claims to a kind of freedom that harms and takes freedom away from others, but also transcodes 'freedom' itself: for an African person like Equiano (and Synder also lists other examples), freedom becomes coterminous with 'death', instigated by imperialism's claustrophobic power of 
subjection and signification. More's counter-discursive stance in relation to Thomson is also revealed here:

Naked on the plat-form lying,

Now we cross the tumbling wave!

Shrieking, sick'ning, fainting, dying,

Deed of shame for Britons brave!

At the savage captain's beck,

Now, like brutes, they make us prance;

Smack the cat about the deck,

And in scorn they bid us dance.

The third line ("Deed of shame for Britons brave!") picks up the sentiment of abject shame encapsulated in Thomson's semanticization of slavery; it is here inverted by More who positions Britons as shameful for subscribing to the ideology and enterprise of enslavement. Crucially, More insists on the fact that shame is not inherent in or essential to any particular positionality (i.e., the enslaved), but is instead defined by one's actions - here the actions of Britons who engage in mass-enslavement. Still more to the point, More insists that shame is not naturally or morally triggered by the fear of a "loss of social recognition" (Wüschner 2017: 99), as it is in Thomson's poem. Instead, shame is triggered - or: should be triggered - by the pain one inflicts on others. As such, and between and beyond the text's victimizing tendencies, More's poem also harbours an insistence on relation - a relation that respects the other as a subject toward whom it bears a responsibility and duty of both care and respect. She carves out just how effortlessly non-relation may slide into sadism and torture, encouraging readers to establish an emotional reaction that perceives of other mothers as fellow human-beings regardless of their physiognomy and/or ethnic background. It is, of course, the view and the discourse of someone speaking from a racially privileged as well as clearly gendered position (as am I). It must be clear, therefore, that the critique of white non-relation practiced here by More - while important in its own, historical context - remains a partial one; the deconstruction of white imperial narcissism is an in itself incomplete project, belonging in a much larger effort of establishing a greater diversity of voices, both current and historical. 


\section{Conclusion}

The poems I have discussed in this chapter speak to (trans-)Atlantic imperialism from different times and different vantage points. Thomson and Brontë follow similar affective patterns whilst More's is a counter-discursive if partially flawed as well as privileged stance that challenges Thomson's normalization of narcissistic imperialism. All engage in/with the affective politics that I now have outlined several times: an investment in select grievability, linked to (white) European bodies; imperial-narcissistic non-relation that drains others of subjecthood and turns them into objects of use (victims included) in order to mirror or humour dominant (in whatever form) images of imperial-patriarchal self-conception; a tendency toward a flexible deployment of in/comparability that is symptomatic of signifying power and oscillates between denoting relating (to some groups and not others) and superiority, either comparative or essential. The trope of the ocean is employed differently by the poems, featuring as a trailblazing facilitator of imperialism as well as ruled subject in "Rule, Britannia!"; as a vast, troubling expanse that needs to be reached across in order to sustain affective relations between a married couple in "The Letter" (which is a sharp counterpoint to the customary, often systematic destruction of family bonds and attachments during the Middle Passage and on the plantations); and as a metaphoric-discursive as well as material counterpoint to triumphalist and normalized imperial non-relation, in "The Sorrows of Yamba". Differently put, the ocean itself is treated as an object of use in ways that appropriate it for the political, ideological, and affective efforts that sustain the plausibility, even morality, of the imperialist enterprise (Thomson, Brontë). In More's poem, the Atlantic becomes a crime scene of slave ships, abuse, death, and desperation, related from the perspective of the enslaved (which is not an 'own-voice'). More renders visible and readable the Atlantic as the figurative and material realm of narcissistic nonrelation that it is - even if this is via a process of appropriation in which she, too, uses oceanic imagery for furthering her own political agenda (in which Christianity is a central one next to abolition). Considering the materials and the authors' standpoints, then, this has been a selection of poems that has offered only glimpses beyond the veneer of white oceanic imagery and instrumentalization, these glimpses coming in from the historical scholarship I have also brought to the scene. It is a compilation in which the biased as much as triumphalist colonial usage of sea metaphors ('rule' of 'the waves', etc.) and material-colonial usage of the ocean is starkly apparent; a context 
in which More's intervention is a pertinent one, as it reminds her majoritywhite readers of the existence of another side of history, however partially represented. As per sentimentalist abolitionist tradition, More demands affective recognition of the enslaved (albeit within rather limited frames), not only condemning the white atrocities committed in and around the AngloAtlantic, but also, and more specifically, heightening awareness of shame's proper roots in care and responsibility. In thus conveying African people's well-being as something that should morally be of interest to the British public, she fosters a critical perspective that is entirely, even pathologically, absent from "Rule, Britannia!" and "The Letter", even though it itself remains heavily gauged by imperial-patriarchal expectations.

In my discussion, I have sought to increase the visibility of normalized structures of imperial non-relation and objectification - practices of 'draining others of subjecthood and agency and turning them into objects of use that reflect power, grandiosity, legitimacy, and so forth, back to the superior, white self. This turning of others into mirror images of preferred self-concepts is an important, if neglected, aspect of 'comparing' and its lack of neutrality. Strategic in/comparability, i.e., the privileged capacity to 'mete out' comparability according to specific goals and preferences, or in relation to some (presumed) facets of an inferiorized, scrutinized other, is, after all, a primary mechanism through which non-relation is negotiated. In historical scholarship, then, research on non-relation and practices of comparing have something to say to each other, revealing affective machinations of specific texts as well as of specific formal practices such as metaphorization ("the fundamental instrumentalism of metaphor"; Stanford Friedman 2013: 36), that are part and parcel of much larger imperial-ideological forms and functions some of which continue to be invisibil(ized) and/or taken for granted to this day. Scrutinising how entire spaces - or oceans - become repositories for white (and/or male) feelings, infused with happiness or excitement, dread or fear; and asking not only "why compare?" (Radhakrishnan) or "why not compare" (Stanford Friedman) but also who compares and to what effects/affects can contribute to forging a meaningful perspective on and/or practice of comparing in the context of the Euro-imperial past of the long eighteenth century, its normalized structures of affective non-relation, and some of these structures' continuing, durée. It is possible that Felski's and Stanford Friedman's tripartite approach of collision, reciprocal defamiliarization, and collage (2013:4) could pose an incentive in this context. Collision's commitment to a multiplicity of voices and listening (inspired by Mary N. Layoun); reciprocal defamiliarization's in- 
vestment in "displac[ing] the Self-Other binary and emphasiz[ing] unknowability" (inspired by Radhakrishnan); collage's refusal of "hierarchy and instrumentalism" and focus on "what texts share" (inspired by modernist Dadaism) (Stanford Friedman 2013: 41-42) - these conjoint methodologies can well encourage, as well as benefit from, a more sustained, critical engagement with the imperial-narcissistic cycles of affective self-aggrandizement and/or white fragility that continue to haunt both public and academic discourses.

\section{Bibliography}

Ahmed, Sarah. The Cultural Politics of Emotion. New York: Routledge, 2015.

Armitage, David. The Ideological Origins of the British Empire. Cambridge: Cambridge University Press, 2004.

Berman, Antoine. The Experience of the Foreign: Culture and Translation in Romantic Germany. Trans. S. Heyvaert. Albany: State Univ. of New York Press, 1992.

Brontë, Charlotte. “The Letter." Poems. Ed. Ellis Currer and Acton Bell. London: Smith, Elder and Co., 1846. 86-89.

Butler, Judith. Notes Toward a Performative Theory of Assembly. Cambridge: Harvard University Press, 2015.

Butler, Judith. Frames of War: When is Life Grievable? London: Verso, 2016.

Chander, Manu Samriti. Brown Romantics. Poetry and Nationalism in the Global Nineteenth Century. Lewisburg: Buknell University Press, 2017.

Chander, Manu Samriti and Patricia A. Matthew. "Abolitionist Interruptions: Romanticism, Slavery, and Genre." Special Issue of: European Romantic Review 29.4 (2018): 431-434.

Colley, Linda. Captives. New York: Pantheon Books, 2002.

Davis, Robert C. Christian Slaves, Muslim Masters: White Slavery in the Mediterranean, the Barbary Coast, and Italy, 1500-1800. New York: Palgrave, 2003.

Diaby, Bakary. "Feeling Black, Feeling Back. Fragility and Romanticism." Symbiosis 23.1 (2019): 117-138.

DiAngelo, Robin. "White Fragility." International Journal of Critical Pedagogy 3.3 (2011): 54-70.

Drichel, Simone. "The Disaster of Colonial Narcissism." American Imago 75.3 (2018): 329-364. 
Felski, Rita and Susan Stanford Friedman. "Introduction." Comparison. Theories, Approaches, Uses. Eds. Rita Felski and Susan Stanford Friedman. Baltimore: Johns Hopkins University Press, 2013. 1-12.

Ferguson, Moira. "British Women Writers and an Emerging Abolitionist Discourse." The Eighteenth Century 33.1 (1992): 3-23.

Festa, Lynn. "Humanity without Feathers." Humanity: An International Journal of Human Rights 1.1 (2010): 3-27.

Gandhi, Leela. Affective Communities: Anticolonial Thought, Fin-de-siècle Radicalism, and the Politics of Friendship. Durham: Duke University Press, 2006.

Klein, Bernhard and Gesa Mackenthun. "Introduction." Sea Changes. Ed. Bernhard Klein and Gesa Mackenthun. London: Routledge, 2004.

Koegler, Caroline. "Posthumanism and Colonial Discourse: Nineteenth Century Literature and Twenty-First Century Critique." Open Library of Humanities 6.2 (2020).

Koegler, Caroline. "Follow the Hatred: The Production of Negative Feeling in Emily Brontë's Wuthering Heights (1847)." NOVEL: A Forum on Fiction 54.2 (2021): 270-286. [Forthcoming].

Lee, Debbi. "Black Single Mothers in Romantic History and Literature." Race, Romanticism, and the Atlantic. Ed. Paul Youngquist. Abingdon: Routledge, 2013. 161-177.

MacLean, Gerald. The Rise of Oriental Travel: English Visitors to the Ottoman Empire, 1580-1720. New York: Palgrave, 2004.

Malreddy, Pavan Kumar. "Imperialist Shame and Indigenous Guilt: George Orwell's writings on Burma." European Journal of English Studies 23.3 (2019): 311-325.

Matar, Nabil. Turks, Moors, and Englishmen in the Age of Discovery. New York: Columbia University Press, 1999.

Matar, Nabil. Britain and Barbary: 1589-1689. Gainesville: University Press of Florida, 2005.

More, Hannah and Eaglesfield Smith, "The Sorrows of Yamba; or, The Negro Woman's Lamentation." Repr. in Slavery, Abolition, and Emancipation: Writings in the British Romantic Period. 8 Vols. Ed. Peter J. Kitson and Debbie Lee. Vol. 4, Verse. Ed. Alan Richardson. London: Pickering and Chatto, 1999 [1795]. 224-231.

More, Hannah. Slavery, A Poem. London: T. Cadell, 1788.

Nyquist, Mary. "The Liberty of Naming," Revisiting Slavery and Anti-Slavery. Towards a Critical Analysis. Ed. Laura Brace and Julia O'Connell Davidson. Cham: Palgrave Macmillan, 2018. 65-96. 
Radhakrishnan, R. "Why Compare?" Comparison. Theories, Approaches, Uses. Eds. Rita Felski and Susan Stanford Friedman. Baltimore: Johns Hopkins University Press, 2013. 15-33.

Reynolds, Larry J. "Slavery and the Civil War." Nathaniel Hawthorne in Context. Ed. Monika M. Elbert. Cambridge: Cambridge University Press, 2018. 5767.

Sandler, Matt. The Black Romantic Revolution. Abolitionist Poets at the End of Slavery. London: Verso, 2020.

Seth, Suman. Difference and Disease Medicine, Race, and the Eighteenth-Century British Empire. Cambridge: Cambridge University Press, 2018.

Simmons, Diane. The Narcissism of Empire. Loss, Rage and Revenge in Thomas De Quincey, Robert Louis Stevenson, Arthur Conan Coyle, Rudyard Kipling and Isak Dinesen. Brighton: Sussex Academic Press. 2007.

Smith, Adam. The Theory of Moral Sentiments. Printed for A. Millar, in the Strand; And A. Kincaid and J. Bell in Edinburgh. London, 1759.

Spivak, Gayatri Chakravorty. "Echo." New Literary History 24.1 (1993): 17-43.

Stanford Friedman, Susan. "Why Not Compare?" Comparison. Theories, Approaches, Uses. Ed. Rita Felski and Susan Stanford Friedman. Baltimore: Johns Hopkins University Press, 2013. 34-45.

Swaminathan, Srividhya, and Adam R. Beach. "Invoking Slavery in the Eighteenth-Century British Imagination." Invoking Slavery in the Eighteenth-Century British Imagination. Ed. Srividhya Swaminathan and Adam R. Beach. Abingdon: Routledge, 2016. 1-19.

Synder, Terri L. The Power to Die: Slavery and Suicide in British North America. Chicago: University of Chicago Press, 2015.

Thomson, James. Alfred: A Masque. Represented Before Their Royal Highnesses the Prince and Princess of Wales, at Cliffden, on the first of August, 1740. London: Printed for A. Millar, 1740. 42-43.

Todd, Dennis. Defoe's America. Cambridge: Cambridge University Press, 2010. Vitkus, Daniel J., ed. Piracy, Slavery, and Redemption: Barbary Captivity Narratives from Early Modern England. New York: Columbia University Press, 2001.

Wüschner, Philipp. "Shame, Guilt, and Punishment." Foucault Studies 23 (2017): 86-107.

Youngquist, Paul, ed. Race, Romanticism, and the Atlantic. Abingdon: Routledge, 2013. 